\title{
Erratum to: Understanding determinants of farmers' investments in sustainable land management practices in Ethiopia: review and synthesis
}

\author{
Zenebe Adimassu $^{1} \cdot$ Simon Langan ${ }^{1} \cdot$ Robyn Johnston ${ }^{2}$
}

\section{Erratum to: Environ Dev Sustain DOI 10.1007/s10668-015-9683-5}

Unfortunately, this article neglected to include acknowledgement of the funder of this research. The authors gratefully acknowledge the CGIAR Research Program on Water, Land and Ecosystems (WLE) for funding this research.

The online version of the original article can be found under doi:10.1007/s10668-015-9683-5.

\section{Zenebe Adimassu}

zenebeteferi@yahoo.com; z.adimassu@cgiar.org

1 International Water Management Institute (IWMI), PO. Box 5689, Addis Ababa, Ethiopia

2 International Water Management Institute (IWMI), PO. Box 2075, Colombo, Sri Lanka 